\title{
Features of treatment of patients with generalized periodontitis with manifestations of psychoemotional stress
}

\author{
Oksana V. Kononova', Anatoliy V. Borysenko ${ }^{1}$, Viktor M. Batig ${ }^{2}$, Michael I. Sheremet ${ }^{3}$ \\ ${ }^{1}$ Department of Therapeutic Stomatology, O.O. Bohomolets National medical university, Kyiv, Ukraine \\ ${ }^{2}$ Department of Therapeutic Stomatology, Bukovinian State Medical University, Chernovtsy, Ukraine \\ ${ }^{3}$ Surgery Department No1 of Bukovinian State Medical University, Chernovtsy, Ukraine
}

\begin{abstract}
Topicality. In the complex treatment of patients with generalized periodontitis, it is necessary to take into account the peculiarities of the etiology and pathogenesis of dystrophic-inflammatory periodontal diseases. Conditionally pathogenic microorganisms of the dental biofilm can exert their pathogenic effect only in case of a slight decrease in the local or systemic immune defense of the patient's body. The presence of stress has a significant impact on the resistance of the organism and, accordingly, on the development, course and treatment of periodontal diseases. This should be taken into account in the complex treatment of patients with generalized periodontitis. Considering this, a medical scheme for the preparation of patients with generalized periodontitis with the presence of psycho-emotional stress using a complex of adrenoblockers has been proposed.

Aim of the study. To determine the clinical efficacy of the proposed complex of adrenoblockers in the complex treatment of patients with generalized periodontitis of the chronic course in the presence of psychoemotional stress.

Material and methods. For this study, 40 patients were selected with a generalized chronic periodontitis with the presence of psychoemotional stress. Medicamental treatment was performed using the proposed premedication with a complex of adrenoblockers. A comprehensive survey of the condition of the periodontal tissues of patients before treatment and as soon as possible after treatment was carried out. To assess the clinical efficacy of treatment, a test of Schiller-Pisarev (1962), PMA index by C. Parma (1961), hygienic index OHI-S (1978), index PBI (H.R. Mühlemann, S. Son, 1971), periodontal index PI (A.L. Russel, 1956) were used. The level of psychological stress was assessed using the DASS-21 and Spielberger-Khanin questionnaires.

Results. As a result of the investigation it was found that the usage of the proposed complex of adrenoblockers in the complex therapy of patients with chronic course of generalized periodontitis with the presence of psychoemotional stress can effectively inhibit the dystrophic-inflammatory process in periodontal tissues. This confirms by the decline in the index PMA, OHI-S, PBI, PI at nearest observation terms.

Conclusions. Usage of the proposed complex of adrenoblockers increases the effectiveness of treatment of chronic course of generalized periodontitis in patients with the presence of psychoemotional stress.
\end{abstract}

Keywords: generalized periodontitis, psychoemotional stress, complex of adrenoblockers

\begin{abstract}
Abbreviations
OHI-S - simplified oral hygiene index

PBI - probing bleeding index

PMA - papillary-marginal-alveolar index

PI - periodontal index
\end{abstract}

\section{INTRODUCTION}

In the complex treatment of patients with generalized periodontitis, it is necessary to take into account the etiology and pathogenesis of dystrophic inflammatory diseases of the periodontium, especially in case of significant influence on them of certain systemic factors $(2,10,16,19,22,23)$. Usually, pathogenic microorganisms of dental biofilm are important in the origin and pathogenesis of dystrophic-inflammatory periodontal diseases. However, they can exert their pathogenic effect only in the event of a certain decrease in the local or 
systemic immune protection of the patient's (host) organism $(1,4,7,15,28,32,33)$. The reduction of the patient's organism resistance is facilitated by systemic diseases, tobacco smoking, psychological stress, etc. $(5,6,31)$. The presence of stress has a significant influence on the organism resistance and, accordingly, on the development, course and treatment of periodontal diseases $(5,6,17,26)$. Its presence should be considered in the case of complex treatment of patients with generalized periodontitis.

For the medical preparation of patients with generalized periodontitis in conditions of psycho-emotional stress was proposed a complex of medicines: Zoxone (0.002 g once a day), Nicergoline $(0.005 \mathrm{~g}$ three times a day), Sibazone $(0.005 \mathrm{~g}$ once a day) $(11,12)$. Our previous experimental (biochemical and pathohistological) studies showed a positive influence of the adrenoblocker complex on the development of experimental periodontal lesions $(13,14)$. This allowed to substantiate the use of this clinical complex of adrenoblockers in the case of treatment of patients with generalized periodontitis in the case of psycho-emotional stress in them.

\section{THE AIM OF THE STUDY}

The purpose of this study was to determine the results of the clinical effectiveness of the proposed complex of adrenoblockers in the complex treatment of patients with generalized chronic periodontitis in the case of psycho-emotional stress in them.

\section{MATERIAL AND METHODS}

To determine the effectiveness of the proposed complex of adrenoblockers, a clinical and laboratory examination and treatment of 40 patients with generalized periodontitis I-II grade of chronic course and manifestations of psychological stress were conducted. These patients were divided into two equal subgroups - the main (30 patients) and the comparison subgroup (10 patients) (Table 1).

Therefore, the main (first) subgroup consisted of thirty $(75.00 \%)$ patients with generalized periodontitis with manifestations of psychological stress, for whom the proposed complex of adrenoblockers was used in complex treatment. The comparison subgroup consisted of ten $(40.00 \%)$ patients with generalized periodontitis with manifestations of psychological stress, for whom a complex treatment was performed similar to the patients of the main treatment subgroup, but without the use of a complex of adrenoblockers.

The level of psychological stress was assessed using questionnaires (DASS-21; Spielberger-Khanin) $(18,25,29)$. The patients completed the Spielberger-Khanin questionnaire, which determined personal and situational anxiety. Subsequently, the responses were evaluated according to the keys and the total scores for all judgments were calculated separately for each of the scales (situational anxiety and personal anxiety).

Patients with generalized periodontitis performed careful removal of all dental deposits with irrigation of periodontal pockets with $0.5 \%$ chlorhexidine solution. Subsequently, thorough scaling of the subgingival surfaces of the teeth roots was performed, with the removal of demineralized cement and dentin (so-called SRP therapy). Medicamental treatment of symptomatic gingivitis was performed according to its form - chronic catarrhal gingivitis equally in patients of both groups. The presence of inflammation in the gingiva was detected and evaluated using the Schiller-Pisarev test (1962) and PMA index by C. Parma (1961) $(24,30)$. The hygienic status of oral cavity was evaluated by using the simplified oral hygiene index - OHI-S $(18,19)$, the assessment of gingival bleeding was made by the probing bleeding index - PBI (HR Mühlemann, S. Son, 1971) (21). In general, the

TABLE 1. Distribution of patients with generalized periodontitis main and comparison subgroups

\begin{tabular}{|c|c|c|c|c|c|c|c|}
\hline \multirow{3}{*}{ Subgroups examined } & \multicolumn{4}{|c|}{ Periodontal disease } & \multirow{3}{*}{$\begin{array}{c}\text { Age } \\
\text { (years) }\end{array}$} & \multirow{2}{*}{\multicolumn{2}{|c|}{$\begin{array}{c}\text { Total number of } \\
\text { patients }\end{array}$}} \\
\hline & \multicolumn{2}{|c|}{ I grade } & \multicolumn{2}{|c|}{ II grade } & & & \\
\hline & abs. & $\%$ & abs. & $\%$ & & abs. & $\%$ \\
\hline The main subgroup & 16 & 53,33 & 14 & 46,67 & 26,67 & 30 & 100,0 \\
\hline Comparison subgroup & 6 & 60,0 & 4 & 40,0 & 25,33 & 10 & 100,0 \\
\hline Total & 22 & 55,00 & 18 & 45,00 & 26,25 & 40 & 100,0 \\
\hline
\end{tabular}


periodontal condition was assessed using the periodontal index (PI) by A.L. Russel (27). The diagnosis of periodontal disease was established according to the classification of M.F. Danilevsky (3). The obtained results were processed by statistical methods using personal computers (20).

\section{RESULTS AND DISCUSSION}

Analysis of the treatment results showed that 4.05 visits were required to achieve an effective result of treatment of patients of the main subgroup with I grade of generalized periodontitis and 5.33 visits were required in patients with II grade of generalized periodontitis. In the comparison subgroup, 5.05 visits of patients with I grade and 6.07 visits of patients with II grade of generalized periodontitis were required to achieve an effective treatment outcome.

As result of complex treatment of patients with generalized periodontitis in all patients of both subgroups, a significant improvement of periodontal tissues condition was achieved. The gingiva become pale pink in colour, without bleeding during probing and the depth of periodontal pockets decreased. There was an improvement in the general well-being of patients, a decrease in the number of manifestations of bad breath.

After treatment, the patients improved the hygienic status of the oral cavity. The OHI-S in patients of the main subgroup with I grade of generalized periodontitis decreased from $1.67 \pm 0.16$ to $0.45 \pm 0.05$ points, in patients with II grade of the disease it decreased from $1.76 \pm 0.15$ to $0.47 \pm 0.04$ points. In patients of the comparison group, the OHI-S in patients with I grade of generalized periodontitis decreased from $1.74 \pm 0.17$ to $0.75 \pm 0.07$ points, in patients with II grade of disease the index decreased from $1.81 \pm 0,16$ to $0.77 \pm 0.07$ points. The difference between the hygiene index of the patients of the main subgroup and the comparison subgroup was statistically significantly different $(\mathrm{p}>0.05)$.

The level of inflammation of gingiva of patients in both experimental subgroups decreased, as evidenced by the negative Schiller-Pisarev test in patients of the main subgroup and in patients of the comparison subgroup. In particular, in the main subgroup of patients with I grade of generalized periodontitis, the Schiller-Pisarev test was negative in 13 of $16(81.25 \%)$ and 11 of $14(78.57 \%)$ patients with II grade of generalized periodontitis. In the comparison subgroup, patients with I grade of generalized periodontitis had a Schiller-Pisarev test negative in 4 of $6(66.67 \%)$ and 3 of $4(75.00 \%)$ patients with II grade of generalized periodontitis. Determination of the quantitative Schiller-Pisarev test by Svrakov showed that in patients of the main subgroup it decreased from $2.4 \pm 0.21$ before treatment to $1.2 \pm 0.01(\mathrm{p}<0.05)$ after treatment: in patients with the I grade - from $2.15 \pm 0.17$ to $1.03 \pm$ 0.08 points and in patients with the II grade from $2.53 \pm 0.19$ to $1.29 \pm 0.09$ points. In the comparison subgroup, it decreased accordingly from $2.6 \pm 0.21$ to $1.5 \pm 0.01(p<0.05)$ : in patients with I grade from $2.43 \pm 0.18$ to $1.19 \pm 0,08$ points and in patients with II grade from $2,76 \pm 0,19$ to $1,41 \pm 0,09$ points. The numerical values of the Schiller-Pisarev sample of patients of both subgroups after treatment were statistically significantly different $(\mathrm{p}<0.05)$.

A decrease in inflammation in periodontal tissues of patients with generalized periodontitis was confirmed by the PMA index. Before treatment, its value in patients of the main subgroup averaged $64.9 \pm 2.9 \%$ : in patients with I grade $-61.3 \pm 2.2 \%$ and with II grade $-66.7 \pm 2.6 \%$. After treatment, the PMA index decreased to an average of $7.3 \pm$ $0.71 \%$ : in patients with I grade - up to $7.1 \pm 0.74 \%$ and with II grade - up to $8.2 \pm 0.8 \%$. In patients of the subgroup, the comparison of the PMA index before treatment averaged $66.55 \pm 2.72 \%$ : in patients with I grade $-64.7 \pm 2.2 \%$ and with II grade -69.3 $\pm 2.8 \%$. After treatment, the PMA index decreased to an average of $9.8 \pm 0.8 \%$ : in patients with I grade up to $8.9 \pm 0.7 \%$ and with II grade - up to $10.9 \pm$ $0.9 \%$. Data from patients in the main and comparison groups were statistically significant $(\mathrm{p}<0.05)$.

Due to the decrease of the level of inflammation of the periodontal tissues in patients, a significant decrease in pathological mobility of the mandibular frontal teeth was observed, almost to normal in patients with I grade of generalized periodontitis. At the same time, a decrease in the depth of periodontal pockets was observed (Table 2).

After comprehensive treatment, patients noted a decrease in gingival bleeding. This was evidenced by the value of the PBI index. In patients with gen- 
TABLE 2. Indicators of periodontal tissue status in patients with generalized periodontitis with manifestations of psycho-emotional stress $(M \pm m)$

\begin{tabular}{|l|l|c|c|c|c|}
\hline \multirow{2}{*}{ Indicators } & \multirow{2}{*}{$\begin{array}{l}\text { Timing of the } \\
\text { survey }\end{array}$} & \multicolumn{3}{|c|}{ I grade } & \multicolumn{2}{c|}{ II grade } \\
\cline { 2 - 5 } & & \multicolumn{3}{|c|}{ Study subgroups } \\
\cline { 2 - 5 } & & Main & Comparison & Main & Comparison \\
\hline \multirow{2}{*}{ OHI-S, points } & Before treatment & $1.67 \pm 0.16$ & $1.74 \pm 0.17$ & $1.76 \pm 0.15$ & $1.81 \pm 0.16$ \\
\cline { 2 - 6 } & After treatment & $0.45 \pm 0.05^{*}$ & $0.75 \pm 0.07$ & $0.47 \pm 0.04^{*}$ & $0.77 \pm 0.07$ \\
\hline \multirow{2}{*}{ Schiller-Pisarev test, points } & Before treatment & $2.15 \pm 0.17$ & $2.43 \pm 0.18$ & $2.76 \pm 0.19$ & $2.76 \pm 0.19$ \\
\cline { 2 - 6 } & After treatment & $1.03 \pm 0.08^{*}$ & $1.19 \pm 0.08$ & $1.29 \pm 0.09$ & $1.41 \pm 0.09$ \\
\hline \multirow{2}{*}{ PMA, \% } & Before treatment & $61.3 \pm 2.2$ & $64.7 \pm 2.2$ & $66.7 \pm 2.6$ & $69.3 \pm 2.8$ \\
\cline { 2 - 6 } & After treatment & $7.1 \pm 0.74^{*}$ & $8.9 \pm 0.7$ & $8.2 \pm 0.8^{*}$ & $10.9 \pm 0.9$ \\
\hline \multirow{2}{*}{ PBI, points } & Before treatment & $2.56 \pm 0.19$ & $2.45 \pm 0.18$ & $2.74 \pm 0.19$ & $2.77 \pm 0.19$ \\
\cline { 2 - 6 } & After treatment & $0.52 \pm 0.05^{*}$ & $0.75 \pm 0.07$ & $0.65 \pm 0.06^{*}$ & $0.82 \pm 0.07$ \\
\hline \multirow{2}{*}{ Periodontal pockets depth, mm } & Before treatment & $2.1 \pm 0.17$ & $2.2 \pm 0.15$ & $3.1 \pm 0.12$ & $3.2 \pm 0.14$ \\
\cline { 2 - 6 } & After treatment & $1.1 \pm 0.1$ & $1.2 \pm 0.12$ & $1.3 \pm 0.12$ & $1.7 \pm 0.12$ \\
\hline \multirow{2}{*}{ PI, points } & Before treatment & $1.63 \pm 0.37$ & $2.15 \pm 0.18$ & $3.34 \pm 0.32$ & $2.63 \pm 0.19$ \\
\cline { 2 - 6 } & After treatment & $0.56 \pm 0.05^{*}$ & $0.72 \pm 0.07$ & $0.71 \pm 0.07^{*}$ & $0.83 \pm 0.08$ \\
\hline
\end{tabular}

Note: *the data are significantly $(p<0.05)$ different from the comparison subgroup data.

eralized periodontitis of the main subgroup, its value decreased from an average of $2.69 \pm 0.19$ points before treatment to $0.67 \pm 0.07$ points after treatment: in patients with I grade - from $2.56 \pm 0.19$ to $0.52 \pm 0.05$ points and in patients with II grade from $2.74 \pm 0.19$ to $0.65 \pm 0.06$ points. In patients of the comparison subgroup, the PBI index decreased on average from $2.58 \pm 0.21$ to $0.88 \pm 0.06$ points: in patients with I grade - from $2.45 \pm 0.18$ to $0.75 \pm 0.07$ and in patients with II grade from 2.77 \pm 0.19 to $0.82 \pm 0.07$ points. Data from patients in the main and comparison groups were statistically significant $(\mathrm{p}<0.05)$.

Changes in the periodontal index (PI) indicate the state of the entire periodontium complex during the treatment stages. In patients with generalized periodontitis of the main subgroup with I grade of disease, its value decreased from $1.63 \pm 0.37$ points to $0.56 \pm 0.05$, and in patients with II grade it decreased from $3.34 \pm 0.32$ to $0.71 \pm 0.07$ points. On average, patients in the main subgroup had a PI index drop from $2.34 \pm 0.3$ to $0.64 \pm 0.06$ points.

\section{REFERENCES}

1. Borgnakke WS, Ylöstalo PV, Taylor GW, Genco RJ. Effect of periodontal disease on diabetes: Systematic review of epidemiologic observational evidence. J. Periodontol. 2013; 84 (4 Suppl.): 13-52.

2. Borysenko AV. Zabolevaniya parodonta. Kiev: VSI «Medicina»; 2013. $456 \mathrm{p}$.

3. Danilevskiy NF. Sistematika bolezney parodonta. Visnik stomatologiï, 1994; 1: 17-21.

4. Genco RJ. Host responses in periodontal diseases: current concepts. J. Periodontol. 1992; 63 (Suppl.): 338-55.
In patients of the comparison subgroup, the PI index on average decreased from $2.29 \pm 0.3$ to 0.84 \pm 0.06 points: in patients with I grade - from $2.15 \pm$ 0.18 to $0.72 \pm 0.07$ score in patients with II grade from $2.63 \pm 0.19$ to $0.83 \pm 0.08$ points. Data from patients in the main and comparison subgroups were statistically significant $(\mathrm{p}<0.05)$.

The results of clinical investigation are presented in table. 2.

\section{CONCLUSIONS}

As a result of researches the obtained data testify to achievement of stabilization of pathological process in a periodontium. All this together demonstrates the beneficial effect of the proposed complex of adrenoblockers on the dystrophic-inflammatory process in the periodontium and indicates the effectiveness of its use in the complex treatment of patients with generalized periodontitis with manifestations of psycho-emotional stress.

5. Genco RJ. Current view of risk factors for periodontal diseases. J. Periodontol. 1996; 67: 1041-1049.

6. Genco RJ, Ho AW, Kopman J, Grossi SG, Dunford RG, Tedesco LA et al. Models to evaluate the role of stress in periodontal disease. Ann. Periodontol. 1998; 3: 288-302.

7. Genco RJ, Borgnakke WS. Risk factors for periodontal disease. Periodontol. 2000. 2013; 62: 59-94.

8. Green JC, Vermillion JR. The oral hygiene index: A method for classifying oral hygiene status. J. Am. Dent. Assoc., 1960; 61: 172-175. 
9. Green JC, Vermillion JR. The simplified oral hygiene index. J. Am Dent. Assoc. 1964; 68: 7-10.

10. Kinane DF. Causation and pathogenesis of periodontal disease. Periodontology, 2001; 25: 192.

11. Kononova OV. Vliyanie linkomicina na sostoyanie parodonta u krys $s$ adrenalinovym stressom. Visnik stomatologiï, 2016; 96 (3): 26-28.

12. Kononova OV, Borysenko AV, Levickiy AP. Vliyanie oral'nyh geley kvertulina i adrenoblokatorov na sostoyanie parodonta u krys s adrenalinovym stressom. Visnik stomatologiï, 2016; 97 (4): 8-11.

13. Kononova OV. Eksperymentalne obgruntuvannia zastosuvannia adrenoblokatoriv. Sovremennaia stomatolohyia, 2018; 2: 86-89.

14. Kononova OV. Patohistolohichne doslidzhennia vplyvu kompleksu adrenoblokatoriv na reheneratsiiu kistky shchelepy. Sovremennaia stomatolohyia. 2018; 3: 36-38.

15. Kornman K. Mapping the pathogenesis of periodontitis: a new look. J. Periodontol. 2008; 79 (8): 1560-1568.

16. Lang NP, Lindhe J. Clinical Periodontology and Implant Dentistry. Somerset: Wiley Blackwell; 2015. 1480 p.

17. LeResche L, Dworkin SF. The role of stress in inflammatory disease, including periodontal disease: Review of concepts and current findings. Periodontol. 2000. 2002; 30: 91103.

18. Lovibond SH, Lovibond PF. Manual for the Depression Anxiety \& Stress Scales. 2nd ed. - Sydney: Psychology Foundation; 1995. $346 \mathrm{p}$.

19. Maschenko I.S. Zabolevaniya parodonta. Dnepropetrovsk: KOLO; 2003. $272 \mathrm{~s}$

20. Mintser OP, Voronenko YuV, Vlasov .V. Obrobka klinichnykh ta eksperymentalnykh danykh u medytsyni. Kyiv: Vyshcha shk.; 2003. $350 \mathrm{p}$.

21. Mühlemann HR, Son S. Gingival sulcus bleeding - a leading symptom in initial gingivitis. Helv. Odontol. Acta, 1971; 15: 107-110.
22. Newman M, Takei H, Klokkevold P, Carranza F. Newman and Carranza's Clinical Periodontology, 13th Edition. St. Louis: Saunders; 2018. $944 \mathrm{p}$.

23. Oganyan ES. Sostoyanie parodonta u bol'nyh insulinzavisimym saharnym diabetom (Kliniko-laboratornye issledovaniya): Avtoref. dis. ... kand. med. nauk: spec.: 14.00.21 «Stomatologiya». S.-Pb., 2001. $20 \mathrm{~s}$.

24. Parma C. Parodontopathien. Leipzig: Barth; 1960. 203 p.

25. Radyuk OM. Vos'mifaktornyy lichnostnyy oprosnik SpilbergeraRadyuka. Minsk: RIVSh.; 2009. 96 p.

26. Reners M, Breex M. Stress and periodontal disease. Int. J. Dent. Hyg., 2007; 5 (4): 199-204.

27. Russel AL. A system of classification and scoring for prevalence surveys of periodontal disease. J. Dent. Res., 1956; 36: 922-925.

28. Soory M. Association of periodontitis wih rheumatoid arthritis and aterosclerousis: novel paradigm in etiopathogenesis and management. Open Access Pheumatol. Res. Rev., 2010; 2: 1-16.

29. Spielberger CD. Test Anxiety Inventory. Sampler Set. Manual, Test, Scoring. Redwood City: Mind Garden; 1980. 240 p.

30. Svrakov D, Atanasova E. Parodontopatii (etiologiya, klinika i lechenie). - Sofiya: Gosudarstvennoe izdatel'stvo «Medicina i fizkul'tura»; 1962. $212 \mathrm{~s}$.

31. Tarasenko L.M., Petrushanko T.A. Stress i parodont. Poltava; 1999. $192 \mathrm{~s}$.

32. Taylor GW, Borgnakke WS. Periodontal disease: Associations with diabetes, glycemic control and complications. Oral Dis. 2008; 14: 191-203.

33. Tonetti MS, Van Dyke TE. Working group 1 of the joint EFP/AAP Workshop. Periodontitis and atherosclerotic cardiovascular disease: consensus report of the Joint EFP/AAP Workshop on Periodontitis and Systemic Diseases. J. Periodontol. 2013; 84 (4 Suppl.): 24-29. 